\title{
Covid-19: e-Learning as a tool for improving the knowledge
}

\section{Covid-19: e-learning como ferramenta para melhoria do conhecimento}

\author{
Maria do Carmo Barros de Melo' (D) mcbmelo@gmail.com \\ Unaí Tupinambás' (D) unaitupi@gmail.com \\ Priscila Menezes Ferri' ${ }^{1}$ pmferri.liu@gmail.com \\ Solange Cervinho Bicalho Godoy' (D) solangecgodoy@gmail.com \\ Rosália Morais Torres ${ }^{1}$ (D) rosaliamoraistorres@gmail.com \\ Vitória Andrade Palmeira' (D) vitoriapalmeira@gmail.com \\ Gabriel Rocha' (D) rochagabriel97@hotmail.com \\ \begin{tabular}{l|l} 
Zilma Silveira Nogueira Reis ${ }^{1}$ (D) & zilma.medicina@gmail.com
\end{tabular}
}

\begin{abstract}
Introduction: Preventing and fighting COVID-19 are of the utmost importance. In this context, the importance of using telemedicine tools has grown, including teleconsultations, epidemiological telemonitoring, remote diagnosis, support, and training of health professionals.

Objective: This article aims to report the results of a distance-training course on SARS-CoV-2 and COVID-19. We analyze the course adherence, the students' profile, pre, and post-test proficiency index and satisfaction with the course.

Methods: This is a cross-sectional study that evaluated data from the course on SARS-CoV-2 and COVID-19. The data were analyzed in terms of distribution and comparisons of means and frequencies. A paired t-test was used to compare the pre and post-test grades. A p-value $<0.05$ was considered significant. Data were collected from the Moodle teaching platform, without identifying the participants.

Results: From March 23 to May 14, the course was offered to 1,008 medical students and health care providers. Most were from the state of Minas Gerais, some from other Brazilian states, and Mozambique. The majority completed the course, with an $89.8 \%$ adherence. The evaluations related to the course, the tutors, the degree of satisfaction, and the security for the professional performance after the course obtained maximum scores. The comparison between the pre and post grades showed proficiency gain $(p<0.0001)$.

Conclusion: The course has contributed to the training of medical students and health professionals from Brazil and Mozambique. The organizing committee was able to prepare students and provide knowledge to professionals with difficulty to access good technical and evidence-based information. After the training, the students were selected to work on university projects aiming at supporting city halls, health departments, and the community.
\end{abstract}

Keywords: E- Learning; Coronavirus Infections; Pandemics; Medical Education.

\section{RESUMO}

Introdução: A prevenção e o combate da Covid-19 são de extrema importância. Nesse contexto, a importância do uso de ferramentas de telemedicina tem crescido, incluindo teleconsultas, telemonitoramento epidemiológico, diagnóstico remoto, suporte e treinamento de profissionais de saúde.

Objetivo: Este trabalho tem como objetivo relatar os resultados de um curso de treinamento a distância que abordou aspectos relacionados ao SarsCoV-2 è Covid-19.

Método: Analisaram-se os seguintes aspectos: adesão ao curso, perfil dos alunos, índice de proficiência pré e pós-teste e satisfação com o curso.Tratase de um estudo transversal que avaliou os dados do curso sobre o Sars-CoV-2 e a Covid-19. Os dados foram analisados em termos de distribuição e comparação de médias e frequências. Um teste t pareado foi usado para comparar as notas do pré e do pós-teste. $O$ valor de $p<0,05$ foi considerado significativo.Coletaram-se os dados na plataforma de ensino Moodle, sem identificação dos participantes.

Resultado: De 23 de março a 14 de maio de 2020, o curso foi oferecido a 1.008 estudantes de Medicina e profissionais de saúde. A maioria era de Minas Gerais, alguns de outros estados brasileiros e de Moçambique. A maioria concluiu o curso com 89,8\% de adesão. As avaliações referentes ao curso, aos tutores, ao grau de satisfação e à segurança para o desempenho profissional após o curso obtiveram pontuação máxima. A comparação entre as séries pré e pós-teste mostrou ganho de proficiência $(p<0,0001)$.

Conclusão: O curso tem contribuído para a formação de estudantes de Medicina e profissionais de saúde do Brasil e de Moçambique. A comissão organizadora conseguiu capacitar alunos e profissionais de saúde com dificuldade de acesso a boas informações técnicas e baseadas em evidências. Após a capacitação, os alunos foram selecionados para atuar em projetos universitários com o objetivo de apoiar prefeituras, secretarias de saúde e comunidade.

Palavras-chave: Educação a Distância; Infecções por Coronavírus; Pandemia; Educação Médica.

${ }^{1}$ Universidade Federal de Minas Gerais, Belo Horizonte, Minas Gerais, Brazil.

Chief Editor: Rosiane Viana Zuza Diniz.

Associate Editor: Rosana Alves.

Received on 09/26/20; Accepted on 07/07/21.

Evaluated by double blind review process. 


\section{INTRODUCTION}

At the end of 2019, the severe acute respiratory syndrome caused by Coronavirus 2 (SARS-CoV-2) was identified as a cause of respiratory infections in Wuhan, a city in China's Hubei province. In February 2020, the World Health Organization (WHO) termed the disease caused by SARS-CoV-2 as coronavirus disease 2019 (COVID-19)'. On March 11, 2020, the WHO declared a pandemic ${ }^{2}$.

Chatterjee et al. $^{3}$ (2020), emphasize the importance of preventing, and fighting the disease, by strengthening health systems, preparing the community to respond to the situation, and promoting the safety of the populations' health worldwide ${ }^{3}$. Information and communication technologies have become important means to support patient care, the community, health services and institutions. Vidal-Alaball et al. $^{4}$ (2020) reported the importance of using telemedicine tools at this time of the pandemic, including teleconsultations, epidemiological, and patient telemonitoring and training of health professionals.

In March 2020, the Federal University of Minas Gerais (UFMG) created a Central Committee to Fight against Coronavirus with several representatives. The main objective is to organize university teaching, assisting, and research actions to support the community in their fight against the pandemic through scientific and technical support. Social isolation measures were adopted, and face-to-face classes were suspended ${ }^{5}$. The Health Campus local committee organized a training course for nursing and medical students using a virtual teaching environment. After the training, the students can work with university assistance projects to support public health, and the community of municipalities in our state.

The course was offered via the Moodle ${ }^{\odot}$ platform of the Health Informatics Center (CINS) of the School of Medicine of UFMG ${ }^{6}$. The article aimed to show the results of the course, to analyze the participants' profile, the proficiency index in the preand post-test, students' adherence, and students' satisfaction with the course.

\section{METHODS}

This is a retrospective and cross-sectional study, using an institutional database without identifying the users. Only the data are analyzed following the General Data Protection Law N. 13.709/2018 and CONEP Resolution 510 (April/2016).

To prepare the course (Fighting the SARS-CoV2 epidemic: Training health students from UFMG to answer the population's questions), a group of teachers and students discussed the format, selected topics, accessed materials, types of tutoring, and evaluation. The initial objective was to train medical and nursing students to work on a project at the UFMG School of Medicine to answer the population's questions about the disease with individualized responses to health professionals and to the general population ${ }^{6,7}$.

Shortly after that, other university assistance projects were developed, including "Adopt your neighborhood in times of coronavirus" in partnership with community associations, city halls and municipal health departments. Students, supervised by university teachers, started to assist in the production of didactic materials, podcasts, and information via radio shows; providing instructions to create homemade masks and face shields; in collecting epidemiological data; in supporting health barriers, as well as acting in information services via mobile use.

The "Tira dúvidas" or "Frequently Asked Questions" interactive homepage was made available on March 30. Several Brazilian municipalities have been accessing the platform since then. Students, after being trained during the course, are now able to answer a large number of questions, quickly, seven days a week, from 7 am to 7 pm, according to a shift schedule with two students per day, supervised by teachers and infectology medical residents. The Health Technology Center (CETES) of the School of Medicine / UFMG developed the system?

Before starting the course, the student must answer a profile questionnaire and take a pre-test. In the end, the student answers a satisfaction questionnaire, and takes a post-test. The satisfaction questionnaire used simple multiple-choice questions and Likert-scale questions to assess the student's opinions about forums, tutors and the adequacy of the course to the objectives.

During the online course, video classes, articles, technical notes and official documents from Brazilian institutions and other countries have been made available. The course was offered via the Moodle ${ }^{\odot}$ platform of the Health Informatics Center (CINS) of the School of Medicine UFMG ${ }^{6}$.

The course contains eight activities, which must be performed every two days, with the following topics: (1) Up-todate $^{1}$ document on COVID-19; (2) how to report the suspected or confirmed cases of COVID-19; (3) how to promote social and home isolation; (4) protocols for approaching the Flu Syndrome in Primary Health Care; (5) clinical and therapeutic aspects of COVID-19; (6) instructions and indication of the use of personal protective equipment (PPE); (7) severity warning signs and flows for the referral of patients with moderate to severe cases of COVID-19; (8) complementary exams for COVID-19.

The activities comprise the creation of questions and answers that may arise from health care providers and the general population regarding each topic addressed in the activities. The tutors compile the "questions and answers", interact with the teachers, and a feedback is provided to the students participating in the course. The course forums of each 
group are used for interaction and for motivational discussions on relevant issues.

At the end of each course, a live meeting is held through the YouTube ${ }^{\odot}$ channel with a compilation of the latest relevant information about the pandemic and the students' questions are sent via chat. The students continue to have access to it for updates, and are invited to participate in all the live meetings.

To receive the certification, the students must access all activities, interact in the forums, send the tasks, and correctly answer more than $70 \%$ of the multiple-choice questions of the post-test. The questions were previously tested and validated by the organizing committee and the tutors.

The course material is updated frequently. There was a demand for the course by undergraduate students from the other years of the medical and nursing programs, and from other public and private universities. In addition, health care providers from several municipalities of the State of Minas Gerais and from other Brazilian States have applied to participate in the course.

The students attending the last year who were approved in the course had their workload considered as educational credits by the Undergraduate Center of our institution. Vacancies for the course were made available for students attending the medical course of the Eduardo Mondlane School of Medicine of Mozambique, under the supervision of teachers with experience in training work from that country.

Data from classes one to five were collected regarding adherence and satisfaction, pre and post-test results, participants' profile, and the number of approvals. The data were analyzed in terms of distribution of means, standard deviation and frequency. A paired t-test was used to compare the pre and post-test grades. Values of $p<0.05$ were considered significant. Student data were collected from the Moodle ${ }^{\circ}$ teaching platform, without identifying the participants.

\section{RESULTS}

The first class of the course started on March 20, and the fifth class ended on May 14, 2020. Each course lasted about 10 to 12 calendar days. A total of 1,008 students were enrolled in the five classes. Of these, 840 completed the entire course (83\%). There was also the participation of health care providers, physicians and nurses, respectively, from the municipalities of Minas Novas [3, (0.30\%), and 20 (1.98\%)]; Veredinha [0 and 2, (0.20\%)]; José Gonçalves de Minas [0 and 4, (0.40\%); Leme do Prado [0 and 14, (1.39\%)] and Chapada do Norte [2, (0.20\%) and $28(2.78 \%)$ ] in the fourth group. From the second class onwards, we had 92 students ( $9.00 \%$ of the total) from Mozambique who participated in the course. The general data of the students' profile are shown in Table 1.
Table 1. Profile data of participants in the SARS-CoV2 training course.

\begin{tabular}{lccc}
\hline & & $\mathrm{N}=1008$ & $\%$ \\
\hline \multirow{2}{*}{ State of origin } & & & \\
& MG & 730 & $72.4 \%$ \\
& SP & 92 & $9.1 \%$ \\
& Others & 186 & $18.5 \%$ \\
\hline \multirow{2}{*}{ Age } & & & \\
& 19 to 21 years & 192 & $18.0 \%$ \\
& 22 or older & 585 & $82,0 \%$ \\
\hline \multirow{2}{*}{ Gender } & & & \\
& Female & 578 & $57.3 \%$ \\
& Male & 430 & $42.7 \%$ \\
\hline
\end{tabular}

Civil status

$\begin{array}{ccc}\text { Married or living with a partner } & 81 & 8 \% \\ \text { Not married } & 927 & 92 \% \\ \text { Others } & 0 & 0 \% \\ \text { Selected via quotas } & 365 & 36.2 \% \\ \text { Scholarship } & 164 & 16.2 \%\end{array}$

Elementary School

Studied all or most of the years in public schools

Studied all or most of the years in private schools

$573 \quad 56.8 \%$

High school

Studied all or most of the years in public schools

Studied all or most of the years in private schools

$525 \quad 52.1 \%$

Took a Technical Course

$\begin{array}{lll}\text { Yes } & 197 & 19.5 \% \\ \text { No } & 811 & 80.5 \%\end{array}$

Took Another University Course

\begin{tabular}{lll} 
Yes & 200 & $19.84 \%$ \\
No & 808 & $80.16 \%$ \\
\hline
\end{tabular}

Completed Another University Course

\begin{tabular}{ccc} 
Yes & 70 & $6.94 \%$ \\
No & 938 & $93.05 \%$ \\
\hline
\end{tabular}

Number of attempts until the student entered University

$\begin{array}{ccc}1 \text { year } & 394 & 39.09 \% \\ 2 \text { years } & 337 & 33.43 \% \\ 3 \text { years } & 163 & 16.17 \% \\ 4 \text { or more years } & 114 & 11.31 \%\end{array}$

Remunerated Work

\begin{tabular}{lrr} 
Yes & 126 & $12.50 \%$ \\
No & 882 & $87.50 \%$ \\
\hline & & Continue...
\end{tabular}


Table 1. (Continuation) Profile data of participants in the SARS-CoV2 training course.

\begin{tabular}{ccc}
\hline & $\mathrm{N}=1008$ & $\%$ \\
\hline $\begin{array}{c}\text { Yes } \\
\text { Had the student already studied the topic? }\end{array}$ & 668 & $66.27 \%$ \\
No & 590 & $58.53 \%$ \\
It was of scientific relevance. & 418 & $41.46 \%$ \\
\hline $\begin{array}{c}\text { Reason for taking the course } \\
\text { To learn more about the topic } \\
\text { To contribute to the fight } \\
\text { against the pandemic } \\
\quad \text { For other reasons }\end{array}$ & 197 & $19.54 \%$ \\
& 730 & $72.42 \%$ \\
\hline
\end{tabular}

MG: Minas Gerais state, Brazil.

SP: São Paulo state, Brazil.

Chart 1 shows the results obtained in the pre and posttest scores, showing a significant increase in the students' knowledge about the topic. The mean of the pre-test grade was 7.93 and the mean of the post-test was 9.56. Paired T-test of the pre and post-test grades showed a statistically significant difference ( $p<0.0001$; confidence interval -1.737 to -1.524$)$. The maximum score was obtained by 157 students $(15.6 \%)$ in the pre-test and 627 students $(72 \%)$ in the post-test $(p<0.001)$. The mean time for the student to answer all the questions in the pre and post-tests was $16.72 \pm 0.05$ and $9.63 \pm 0.03$ minutes respectively, with a minimum of 2 and a maximum of 60 minutes in both tests $(p<0.0001)$.

Adherence to the course was also assessed; of the total enrolled, 872 (87\%) were students, of which 54 (5\%) never accessed the teaching platform and 82 (8\%) did not finish the course. Regarding participation, Table 2 shows data on the percentage of students who completed the course, the reasons for not having access to all of the available material (when applicable) and the evaluation of the interaction through the forums.

The assessment of the tutors' performance, as support for students, is shown in Chart 2, based on the answers to two questions.

When assessing whether the participants felt secure to answer the population's questions after the training, more them $90 \%$ of the participants totally agreed with it. In addition, when participants were asked about the identification of the signs of disease severity, more than $90 \%$ of them totally agreed that after the course they would feel more comfortable doing it.

When assessing the overall learning from the course (Chart 3) and the fact that the acquired knowledge provided them with greater security in clinical practice, over $90 \%$ of the participants strongly agreed with it.

Chart 1. Comparison of grades obtained in the pre-test and post-test of the SARS-CoV2 training course $(\mathrm{N}=1008)$.

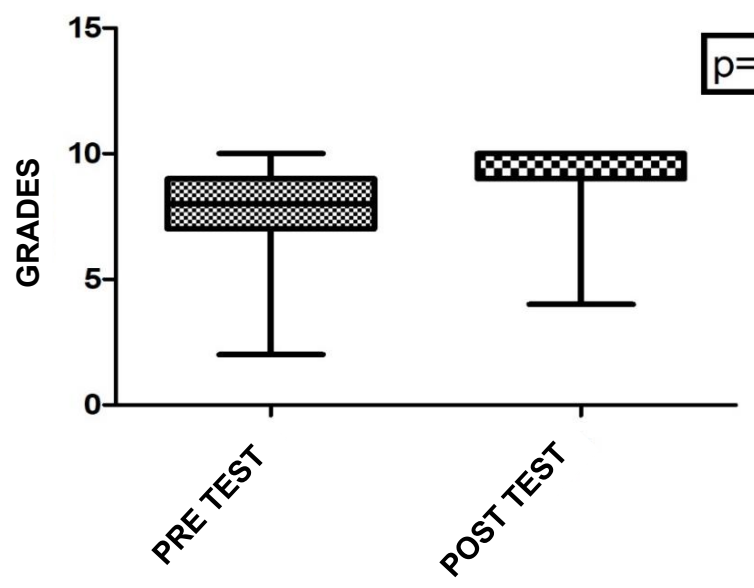

Table 2. Data obtained from the satisfaction questionnaire at the end of the SARS-CoV2 training course.

\begin{tabular}{cc}
\hline Data & $\begin{array}{c}\text { Number of students } \\
\mathbf{N}(\%)\end{array}$ \\
\hline Students who completed the course. & $\mathrm{N}=840$ \\
Did the student have access to all of the course content? \\
Yes & $754(89.8 \%)$ \\
No & $48(5.7 \%)$ \\
Did not answer & $38(4.5 \%)$ \\
\hline
\end{tabular}

Reasons for NOT accessing the entire course: $(n=48)$

\section{Lack of time}

Difficulty in accessing the Internet

Personal reason

Lack of practice in using distance learning platforms

$$
\text { Disinterest }
$$

$12(25.0 \%) / 1.4 \%$ of the total students

$9(18.7 \%) / 1.0 \%$ of the total students

15 (31.2\%) / 1.8\% of the total students

$10(20.8 \%) / 1.2 \%$ of the total students

2 (4.2\%) / $0.2 \%$ of the total students

Were the group forums well developed?

$\begin{array}{ll}\text { Yes } & 583(69.40 \%) \\ \text { No } & 257(30.60 \%)\end{array}$

Were the general forums well developed?

$\begin{array}{ll}\text { Yes } & 580(69.04 \%) \\ \text { No } & 260(30.95 \%)\end{array}$

Did the tutors provide the necessary assistance?
Yes
$769(91.55 \%)$
No
$71(8.45 \%)$ 
Chart 2. Interaction with tutors (on line) through the forums in the SARS-CoV2 training course. (A) Question 1: "Do the questions raised by the tutors help me to think critically?"; (B) Question 2: "Did the tutors answer your questions properly?"

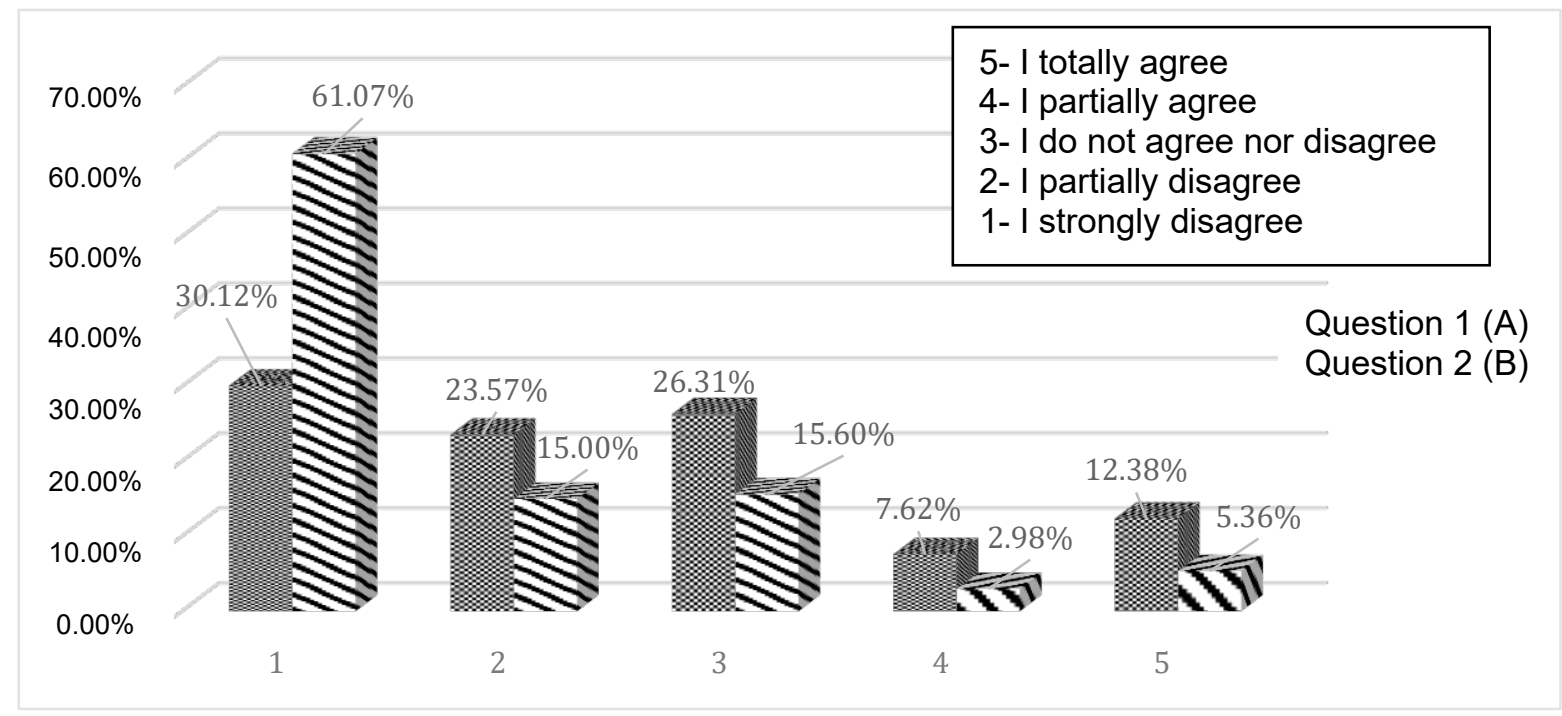

Chart 3. Evaluation of participants in relation to training in SARS-CoV2 as a whole. (A) statement 1: "After training I feel safer to answer the population's questions. "(B) statement 2:" After training, I feel more secure to recognize the signs of the severity of the disease. "(C) statement 3:"After training I feel more secure to act professionally". (D) statement 4: "You would recommend this training to a colleague."

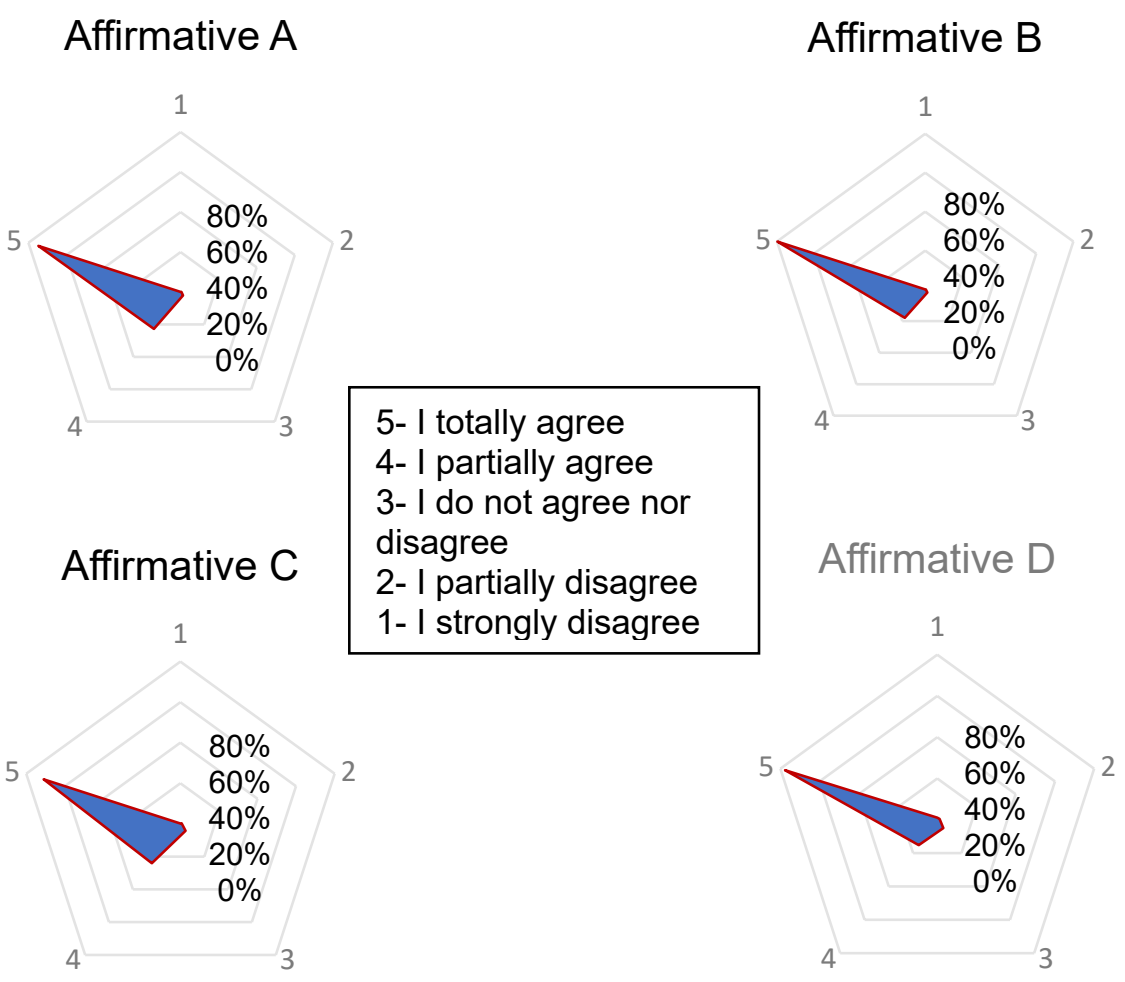

\section{DISCUSSION}

Li et $\mathrm{al}^{9}$ (2020) emphasize that the use of social media can help characterize the distribution of the disease and disseminate knowledge, good attitudes, and behaviors for the entire population. Telecommunication tools have become more valued as it offers social proximity without physical proximity.
Virtual self-care, virtual health care, finance management and payments via the web and distance learning were quickly implemented ${ }^{8}$. These measures seem to be critical for the initial control of an outbreak.

The idea of the training course arose from the demand to train undergraduate medical and nursing students, as well as 
health care providers. The course might help them to intervene in the process of illness by teaching preventive measures, health promotion, and the dissemination of good practices, thus avoiding the spread of fake news.

The assistance actions promoted by the University include social media environments, with the participation of students that have been approved in the course. Online activities to help the public health crisis are becoming increasingly important and intertwined. Social media offers the opportunity to quickly make relevant information public. Health systems must work to build national and international disease detection and surveillance systems by monitoring the media, as reported facts can lead to an important discovery. It is also necessary that public health institutions be more proactive and agile to fight against the spread of fake news ${ }^{10}$.

A study conducted in South Korea investigated the transmission of information and news-sharing behaviors about COVID-19 via Twitter ${ }^{11}$. Most of the news depicted nonmedical pictures, but the repercussion of the ones that claimed to provide medical information about COVID-19 was greater, even if they were not true. Analysis of social media networks cannot replace public health work; however, monitoring public conversations and news that spread quickly can help in decision-making processes ${ }^{11}$.

Especially during the initial period of social isolation, there was a great demand from several Brazilian municipalities, regarding a number of doubts by health care providers and the community. The "Tira dúvidas" or "Frequently Asked Questions" page (www.tecnologia.medicina.ufmg.br/cetesenfrentamento) has helped to spread important knowledge regarding the prevention and treatment of COVID-197.

On January 26, 2020, the WHO made an open distancelearning course available on its teaching platform named "OpenWHO.org". This online course was provided in 13 languages. On March 25, 2020, the COVID-19 introductory course totaled 232,890 registrations in all languages for health care providers and other professionals. The top 10 countries with the most users were Argentina, Chile, Colombia, Ecuador, India, Mexico, Peru, Spain, the United Kingdom, and the United States ${ }^{12}$.

According to the WHO (2019), "health literacy represents cognitive and social skill factors that determine the motivation and ability of individuals to gain access to, to understand and use information so that they can promote and maintain good health"13. Research shows that the WHO is a respected source of information during epidemics, suggesting that the organization has many resources to stimulate health behaviors ${ }^{14}$. Similarly, but on a much smaller scale, we can say that UFMG is a respected source of information. The demand for our course was high, due to the participants' confidence in the quality of the provided information.

The evaluation process is one of the important components in a teaching-learning process ${ }^{15}$. Thus, in addition to access all activities, the students needed to send the tasks and interact with colleagues and tutors. The students were also required to attain a score of at least $70 \%$ in the post-test. A large number of students successfully finished the course. There was an increase in proficiency when comparing the percentage of correct answers in the pre and post-test, showing that the course contributed to learning about the topic.

Julia et al. ${ }^{16}$ (2020) reported on the reorganization of the health service in France in the face of the pandemic, with a high investment aimed at teleconsultations. The authors emphasize that the poorest population or those with difficulty in accessing the Internet and digital technologies or with language barriers are left without adequate assistance ${ }^{16}$.

The participation of primary health care professionals is essential at this time to assist the population with and without a COVID-19 diagnosis. Patients need to maintain control of chronic diseases, common health situations and essential care, such as vaccination ${ }^{16}$. Many students who were trained by our course will be at the frontline of emergency services or primary care, making good technical and scientific decisions.

The health care providers who work in public services in municipalities lacking resources for health and with little access to information were also trained in our course. Souza et al. ${ }^{17}$ (2020) studied the primary health care service provided by the Unified Health System (SUS) in Brazil. Many investments have been made regarding the acquisition of equipment and increase in the number of hospital beds and intensive care unit beds for patients with moderate to severe cases of COVID-19. The authors also affirmed that primary care services need to be improved as an instrument to avoid the collapse of the health system, preventing deaths and morbidity from COVID-19 and other chronic diseases or conditions that require assistance ${ }^{17}$.

Adherence to the course was $83 \%$. Only 82 students $(8.2 \%)$ gave up before accessing the course. The evaluation of adherence to distance education courses is hampered by several factors. Berge and Huang ${ }^{18}$ (2004) use the terms evasion, permanence, or retention, and persistence. Evasion is characterized as a decline in the number of students from the beginning to the end of the course. Permanence or retention is considered when the student continues the course until completion. The latter depends a lot on the format of the course and on the coordinators' work. Persistence results from the students' decisions to continue participating in the course ${ }^{18}$.

Regarding the profile of the participants, it was possible to verify that the majority is from the state of Minas Gerais, 
whereas some are from São Paulo and other Brazilian states, and a few from Mozambique. Kuhn et al. ${ }^{19}$ (2017) analyzed the characteristics of students in a distance technical course. The authors reported that most participants were females (76\%). They also verified that $54.1 \%$ of the students chose a distance technical course for reasons of opportunity and that $85 \%$ were satisfied with the accessibility to the platform and with tutoring. In addition, $88.5 \%$ were satisfied with the platform usability and $90 \%$ with the course dynamics ${ }^{19}$.

Online distance education allows the participants to adapt their schedules to daily life. It also provides collaborative learning through interaction networks and exchange of experiences between participants ${ }^{20,21}$. The degree of student satisfaction with our course was high, as well as the evaluation of the course, platform and tutoring. Tutors encouraged students to think critically and helped them to interact at the forums. The scores regarding the feeling of security after the training to answer the population's questions, to identify the signs of disease severity and to act professionally were also very good. In addition, participants affirmed that they would recommend this training to a colleague.

Bauchner and Sharfstein 22 (2020) published an editorial concerning the importance of involving medical students in actions to support public health in the United States of America (USA). The course reported herein allowed students from nursing and medical schools to take part in assistance projects from UFMG, aiming at supporting municipalities to prevent and to assist the population during this pandemic.

About $30 \%$ of individuals infected with SARS-CoV-2 develop COVID-19 disease and approximately 25\% require hospitalization. Numerous therapies are being developed, and rapid improvements are anticipated. Because of disinformation, only approximately $50 \%$ of the U.S. population plans to receive a COVID-19 vaccine. Telecommunication could help to disseminate accurate information and provide the best care for those who become sick. Different vaccines have been manufactured worldwide and it is of the utmost importance to convince the Governments to get people vaccinated and, concomitantly, to continue wearing face masks and avoid agglomerations, according to the epidemiological situation in each country ${ }^{23}$.

As one of the limiting factors of this study, we have the fact that it is a cross-sectional study, with a relatively small sample size. Another factor is that our study included only medical and nursing students and health care providers from our country and, to a lesser extent, from Mozambique. Nevertheless, it is worth mentioning that the course provided by the WHO was also freely available to all countries. Thus, equity was valued regarding access to information, regardless of the place where the participant lives. The interaction between a public university such as UFMG and the community is essential for health services and for the dissemination of scientific information, especially in times of pandemic.

\section{CONCLUSION}

The course "Fighting against the SARS-CoV2 pandemic: Training health students from UFMG to answer the population's questions" has frequent updates, since COVID-19 is a new disease and many controversies and doubts still need clarification. The course has collaborated to train nursing and medical students, and health care providers, from various Brazilian municipalities and from Mozambique. The organizing committee was able to act quickly to prepare students who were close to the end of the medical undergraduate program to assist patients with COVID-19. Adherence to the course was high and also provided technical knowledge and evidencebased scientific information to health care providers who work at remote and places with few resources.

\section{ACKNOWLEDGMENTS}

We would like to thank all tutors (students and teachers) and technical-administrative staff who provide services to FM / UFMG who contributed to the success of the course "Fighting against the SARS-CoV2 epidemic: Training for UFMG health students to answer the population's questions". We also thank the professionals working on the "Tira dúvidas" project, especially the workers and other professionals linked to CINS and CETES of FM / UFMG. Special thanks to the Extension Center and the Board of FM / UFMG, who gave us all the support to register and start the course on an emergency basis.

\section{AUTHORS' CONTRIBUTION}

Maria do Carmo Barros de Melo, Unaí Tupinambás and Priscila Menezes Ferri: Organization of the conception and design of the study and analysis of study data. Solange Cervinho Godoy and Rosália Morais Torres: substantial contributions to the conception and design of the study; critical review of important intellectual content. Vitória Andrade Palmeira and Gabriel Rocha: substantial contributions to the conception or design of the study; drafting of the manuscript. Zilma Silveira Nogueira Reis: substantial contributions to the acquisition, analysis, and interpretation of study data; critical review of important intellectual content.

\section{CONFLICTS OF INTEREST}

The authors declare no conflicts of interest.

\section{SOURCES OF FUNDING}

The authors declare no sources of funding. 


\section{REFERENCES}

1. Pascarella G, Strumia A, Piliego C, Bruno F, Del Buono R, Costa F et al. COVID-19 diagnosis and management: a comprehensive review. J Intern Med. 2020 Aug;288(2):192-206.

2. World Health Organization. WHO Director-General's opening remarks at the media briefing on COVID-19 - 11 March 2020. 2020 [access in 9 Jun 2020]. Available from: https://www.who.int/dg/speeches/detail/whodirector-general-s-opening-remarks-at-the-media-briefing-on-covid-19--11-march-2020.

3. Chatterjee P, Nagi N, Agarwal A, Das B, Banerjee S, Sarkar S, et al. The 2019 novel coronavirus disease (COVID-19) pandemic: A review of the current evidence. Indian J Med Res. 2020;151(2 \& 3):147-59.

4. Vidal-Alaball J, Acosta-Roja R, Hernández NP, Luque US, Morrison D, Narejos PS, et al. Telemedicine in the face of the COVID-19 pandemic. Aten Primaria. 2020;52(6):418-22.

5. Universidade Federal de Minas Gerais. Comitê Permanente de Acompanhamento das Ações de Prevenção e Enfrentamento do Novo Coronavírus. 2020 [access in 9 Jun 2020]. Available from: https://ufmg.br/ coronavirus.

6. Centro de Informática em Saúde. Plataforma Moodle. 2020 [access in 1 Jun 2020]. Available from: https://moodle.medicina.ufmg.br.

7. Centro de Tecnologia em Saúde. Faculdade de Medicina. Universidade Federal de Minas Gerais. Tira dúvidas da população. 2020 [access in 9 Jun 2020]. Available from: www.tecnologia.medicina.ufmg.br/ cetesenfrentamento.

8. Berwick DM. Choices for the "New Normal". JAMA. 2020;323(21):2125-6. doi: 10.1001/jama.2020.6949.

9. Li J, Xu Q, Cuomo R, Purushothaman V, Mackey T. Data Mining and Content Analysis of the Chinese Social Media Platform Weibo During the Early COVID-19 Outbreak: Retrospective Observational Infoveillance Study. JMIR Public Health Surveill. 2020;6(2):e18700. doi:10.2196/18700.

10. Abd-Alrazaq A, Alhuwail D, Househ M, Hamdi M, Shah Z. Top Concerns of Tweeters During the COVID-19 Pandemic: Infoveillance Study. J Med Internet Res. 2020 Apr 21;22(4):e19016. doi: 10.2196/19016.

11. Park HW, Park S, Chong M. Conversations and Medical News Frames on Twitter: Infodemiological Study on COVID-19 in South Korea. J Med Internet Res. 2020:5;22(5):e18897. doi: 10.2196/18897
12. Utunen H, Ndiaye N, Piroux C, George R, Attias M, Gamhewage G. Global Reach of an Online COVID-19 Course in Multiple Languages on OpenWHO in the First Quarter of 2020: Analysis of Platform Use Data. J Med Internet Res. 2020:27;22(4):e19076. doi:10.2196/19076.

13. World Health Organization. The WHO health promotion glossary. 1998 [access in 9 Jun 2020]. Available from: http://www.who.int/ healthpromotion/HPG/en/.

14. Kendal E. Public health crises in popular media: how viral outbreak films affect the public's health literacy. Med Humanit. 2019 Jan 19:medhum-2018-011446. doi: 10.1136/medhum-2018-011446. Epub ahead of print.

15. Troncon LEA. Avaliação do estudante de medicina. Medicina, Ribeirão Preto.1996:29(4):429-39. doi: 10.11606/issn.2176-7262.v29i4p429-439.

16. Julia C, Saynac Y, Le Joubioux C, Cailhol J, Lombrail P, Bouchaud O. Organising community primary care in the age of COVID-19: challenges in disadvantaged areas. Lancet Public Health. 2020 Jun;5(6):e313. doi: 10.1016/S2468-2667(20)30115-8.

17. Souza CDF, Gois-Santos VT, Correia DS, Martins-Filho PR, Santos VS. The need to strengthen Primary Health Care in Brazil in the context of the COVID-19 pandemic. Braz Oral Res. 2020;34:e047. doi: 10.1590/18073107bor-2020.vol34.0047.

18. Berge Z, Huang Y. A model for sustainable student retention: A holistic perspective on the student dropout problem with special attention to e-learning. Deosnews, 2004:13(5):1-26.

19. Kuhn N, Hofler CE, Silva SS. Análise da satisfação dos estudantes de um curso técnico EaD. Rev. NEaD-Unesp. 2017:3(1):86-114.

20. Alves TMF, Menezes AHN, Vasconcelos FMBP. Crescimento da educação à distância e seus desafios: uma revisão bibliográfica. Revista de Educação da Universidade Federal do Vale do São Francisco. 2014:4(6):63-74.

21. Valente JA, Moran JM. Os modelos educacionais na aprendizagem on-line. São Paulo: Summus Editorial, 2007.

22. Bauchner H, Sharfstein J. A Bold Response to the COVID-19 Pandemic: Medical Students, National Service, and Public Health. JAMA. 2020 May 12;323(18):1790-1. doi: 10.1001/jama.2020.6166.

23. Carbone M, Lednicky J, Xiao SY, Venditti M, Bucci E. Coronavirus 2019 Infectious Disease Epidemic: Where we are, What Can Be Done and Hope For. J Thorac Oncol. 2021;16(4):546-71. doi:10.1016/j.jtho.2020.12.014.b 